\title{
Using NPR's Planet Money Podcast in Principles of Macroeconomics
}

\author{
William J. Luther \\ Kenyon College
}

\begin{abstract}
Unfamiliar with aggregate concepts like gross domestic product and inflation, many introductory students struggle to understand the big ideas in macroeconomics. Macroeconomic educators typically respond with boring lectures aimed at bringing students up to speed, or by jumping to the interesting topics their students are not yet prepared to consider. In an effort to combat this problem, I have incorporated NPR's Planet Money podcast into my Principles of Macroeconomics course. I describe the podcast and provide a list of episodes others might find useful. In my experience, students enjoy listening to the assigned episodes. They report that the podcast made them more interested in the principles course, helped them understand the relevance of macroeconomics, and increased their understanding of many macroeconomic issues. Most students also feel more comfortable discussing macroeconomic issues having listened to the podcast. And nearly half of those students surveyed say they will continue listening to the podcast after the course ends.
\end{abstract}

JEL Codes: A1, A22

Keywords: macroeconomics, National Public Radio, Planet Money, podcasts, teaching

\section{Introduction}

Ben Stein's monotonous lecture on the effects of the HawleySmoot Tariff Act is painful to watch, but it points to a big problem macroeconomics educators face. In contrast to Principles of Microeconomics, where students encounter decisions similar to those they make every day, Principles of Macroeconomics requires conceptualization of unfamiliar aggregate constructs like gross domestic product and inflation. As a result, many students find it difficult to understand the big ideas in macroeconomics. Since students do not know enough about the core concepts to consider interesting questions from the outset, many macroeconomics educators limit themselves at the principles level to boring lectures aimed at bringing students up to speed. Others, like Stein, drone on 
answering their own questions about the interesting topics their students are not yet prepared to consider. In both cases, some students inevitably disengage (leaving the instructor asking, "Anyone? Anyone?") and never reach a level where open discourse is possible.

Many teacher-scholars reference popular media in the classroom or in out-of-class exercises to illustrate the practical relevance of the course material while capturing students' attention. Diamond (2009), Ghent, Stone, and Mateer (2011), Hall (2005), Holian (2011), Mateer (2004), and Mateer and Stephenson (2011) use video clips from popular movies and television shows to illustrate economic concepts. Hall and Lawson (2008) and Hall et al. (2008) use lyrics from popular songs. Lawson (2006) constructs assignments with comic strips. Along these lines, I have incorporated NPR's Planet Money podcast into my introductory macroeconomics course. ${ }^{1}$

In what follows, I describe the podcast and provide a list of episodes others might find useful. I also identify corresponding chapters from Tyler Cowen and Alex Tabarrok's Modern Principles: Macroeconomics (2011). After briefly reviewing how I came to use NPR's Planet Money in Principles of Macroeconomics, I present the results of a survey given to students after completing my course. I find that students enjoy listening to the assigned episodes. They report that it made them more interested in the principles course, helped them to understand the relevance of macroeconomics, and increased their understanding of many macroeconomic issues. Most students also feel more comfortable discussing macroeconomic issues having listened to the podcast. And nearly half of those students surveyed say they will continue listening to the podcast after the course ends. As such, I recommend that other instructors incorporate NPR's Planet Money podcast into their own introductory courses in macroeconomics.

\section{The Planet Money Podcast}

Planet Money is a podcast and blog produced by National Public Radio (NPR) in the United States. When the podcast launched in September 2008, its primary mission was to cover the financial crisis. In the time since, its coverage has expanded to include a broader range of economic issues. Episodes are hosted by Alex Blumberg, Zoe Chace, Adam Davidson, Jacob Goldstein, Chana Joffe-Walt,

\footnotetext{
1 Moryl (2013) uses NPR's Planet Money podcast in undergraduate microeconomics courses, though the assignment differs somewhat from that presented herein.
} 
Caitlin Kenney, David Kestenbaum, and/or Amy Stevens. New episodes are usually released on Tuesday and Friday each week.

Several characteristics make NPR's Planet Money podcast suitable for use in a standard introductory macroeconomics course. Each episode is roughly twenty minutes long. Their relatively short duration and casual tone mean students can squeeze in an episode while getting ready in the morning, on their way to and from class, or while working out at the gym. By enabling them to make use of time that would otherwise be wasted, the podcast gives students more economics at little opportunity cost.

An episode typically covers a single economic issue. ${ }^{2}$ Each issue is approached from an interesting angle with a healthy dose of humor. For example, episode 392, "Keeping the Biggest Secret in the US Economy" (NPR 2012a), presents the somewhat extreme measures taken by the Bureau of Labor Statistics to ensure monthly employment data are not released ahead of schedule. (Among other things, economists with clearance have to take out their own trash.) Along the way, students learn who collects these data, how they are collected, and the frequency with which they are releasedinstitutional details often glossed over or omitted entirely in an introductory macroeconomics course.

Planet Money presents controversial issues in a fair and balanced manner without tempering disagreement. Consider, for example, the two-part series on the gold standard. In the first part, episode 252, "The Gold Standard" (NPR 2011a), David Kestenbaum and Jacob Goldstein interview finance writer James Grant, who is identified as "the go-to guy on Wall Street if you want to hear the pro-gold standard argument” (6:45). They establish Grant as a well-respected expert who appears regularly on television and who writes op-eds for reputable news outlets including the New York Times and the $W$ all Street Journal. They note his successful investment newsletter, Grant's Interest Rate Observer, which, as Kestenbaum remarks, "investors pay a lot of money to get" (7:12). Even when describing Grant as a "charming curmudgeon," they do so in a way that is playful, amusing, and not at all disrespectful (7:20).

In the second part, episode 253, "The Gold Standard, R.I.P." (NPR 2011b), Kestenbaum and Goldstein present the view of economists who oppose the gold standard. The episode opens with a

2 Occasionally, Planet Money will repackage several short stories that have aired on other programs, including Morning Edition, All Things Considered, and This American Life, into a single episode. 
strong quote from Fed Chairman Ben Bernanke: "It's not practical to go to a gold standard. I think we have to stay with a central bank. But certainly we are modifying our views on the financial system and on monetary policy, reflecting what's happened in the last few years." The rest of the episode pulls no punches. Economist Randy Parker describes the gold standard as "a pernicious anachronism that should be kept in the history books" (2:41). "And to think that modern people today want to speak about its resurrection," Parker continues, "should absolutely horrify and terrify anyone who understands economics-even a little bit."

Regardless of one's view, these two episodes are useful for informing a discussion for undergraduates. With little effort, students are made acutely aware of the trade-off between long-run purchasing power stability and short-run monetary policy flexibility. Instructors can push back against the claim that the gold standard prolonged the Great Depression and reemphasize the importance of stable prices for investment. Alternatively, they might emphasize the long-run consequences of short-run increases in unemployment and present students with data supporting the episode's conclusion. Either way, the podcast provides a useful starting point for a potentially lively debate.

A list of select episodes from NPR's Planet Money podcast is included in the appendix. ${ }^{3}$ For reference, I also identify corresponding chapters from Tyler Cowen and Alex Tabarrok's Modern Principles: Macroeconomics, second edition. As I explain in the following section, I have used many of these episodes in class and, in general, am satisfied with the results.

\section{Assigning the Planet Money Podcast}

I recognized the common trade-off between breadth and depth during my first semester teaching Principles of Macroeconomics at Kenyon College and, as a result, began thinking of ways to expand the feasibility set at little cost. I wanted to increase awareness of macroeconomic concepts and illustrate the practical relevance of the material before students arrived in class. Assigning additional readings would significantly increase the burden for students, and it is far from clear that the benefits would be all that large. Arranging to meet with students outside of class might yield greater benefits, but at a

\footnotetext{
3 A continuously updated list of episodes can be found on the author's webpage: http://www.wluther.com/Site/Teaching.html.
} 
significantly high cost for the instructor and a nontrivially high cost for students. The solution, it seemed to me, was to assign a podcast where the student-with little additional time and effort-could encounter interesting questions and hear how economists and economic journalists use data to resolve them. After reviewing several podcasts, I settled on NPR's Planet Money. ${ }^{4}$

I incorporated the Planet Money podcast into one section of Principles of Macroeconomics. ${ }^{5}$ The episode selection process was undoubtedly the most arduous aspect. First, I formed a list of episodes I believed were both interesting and pertinent to the material covered in the course. Then, I began mapping the episodes to chapters in the assigned textbook. My objective was to assign two episodes per week, with fewer episodes assigned in the first week (when students are adjusting to their new schedules) and around exams (when they tend to be busy cramming). ${ }^{6}$ This process proved challenging in that multiple episodes were required for some chapters (e.g., I spend two weeks on economic growth and the Solow model-meaning four episodes on the topic would be needed to meet my goal of two per week) and some topics (e.g., the federal budget, political economy, and public choice) were not covered over a long enough period to warrant inclusion of all the episodes relevant to the subject. As a result, I assigned fewer than two episodes in some weeks and omitted a few excellent episodes.

It is worth noting that some episodes map more closely to the material than others. For example, episode 254, "Inside the Great Depression" (NPR 2011c), combs through the personal diary of

\footnotetext{
${ }^{4}$ Other podcasts considered include EconTalk, FEE - Austrian Economics Seminar Podcast, Freakonomics Radio, and London School of Economics Lectures and Events. Although these podcasts might be usefully incorporated into other courses, the length and/or range of topics covered in these podcasts were not consistent with the objective outlined herein.

5 Although the section is capped at 30, only 23 students subscribed. Principles of Microeconomics is a prerequisite for Principles of Macroeconomics at Kenyon College. As such, most students take the latter during the spring semester. Those taking Principles of Macroeconomics in the fall semester either (1) scored high enough on the AP exam to skip Principles of Microeconomics or (2) are not progressing through the courses in the usual timeframe. The latter group includes nonmajors, late-decision majors, majors who were unable to get into a section in the spring, and those needing to repeat either Principles of Microeconomics or Principles of Microeconomics. Casual observations suggest there is no significant difference in composition across semesters.

6 The course met three times a week; episodes were typically assigned for Monday and Friday classes.
} 
Benjamin Roth, a lawyer living during the Depression. It presents a gripping firsthand account of the period and, as such, pairs nicely with chapter 13, section 6, "Understanding the Great Depression: Aggregate Demand Shocks and Real Shocks," of Cowen and Tabarrok's textbook. Episode 416, "Why the Price of Coke Didn't Change for 70 Years" (NPR 2012b), by contrast, is less relevant. Although it provides an excellent example of sticky prices, the history of Coke is not essential material for an introductory macroeconomics course; the experience of the Great Depression almost certainly is.

Assigned episodes are listed alongside readings in the course syllabus. Following Hall (2012), who assigns audio interviews with professional economists, I asked students to fill out a 4" $\times 6$ " notecard for each episode. On the front of the card, I instructed them to briefly summarize the episode. On the back, they could ask a question about something they did not understand or state something they disagreed with or wished to discuss further. I graded and returned notecards promptly, making notations and explanations as necessary. All combined, the twenty-three notecards assigned were worth 10 percent of a student's overall grade. ${ }^{7}$

Incentives seem to have been properly aligned. ${ }^{8}$ The completion rate was very high, with 96.41 percent (510/529) of assigned notecards submitted. ${ }^{9}$ Moreover, the summaries and questions submitted consistently demonstrated that students were familiar with

\footnotetext{
7 Students were told that a simple scoring procedure would be employed. Not submitting a notecard by the due date for the assigned podcast would result in a zero. No late assignments were accepted in the course, but students were permitted to turn in notecards early. Submitting a notecard that demonstrated familiarity with and reflection on the material would result in one point. Those submitting a notecard that failed to demonstrate familiarity or reflection would earn partial credit, typically amounting to 0.5 or 0.75 points. A student's scores would then be averaged and multiplied by ten to calculate the total number of points contributing to the final grade in the course. Students seemed to understand the simple scoring procedure prior to submitting notecards.

${ }^{8}$ Prior to full-scale adoption, the project was piloted by assigning five episodes in a single section of Principles of Macroeconomics. Then, in the semester immediately following the pilot, I attempted full-scale adoption for the first time in two sections of Principles of Macroeconomics. In both cases, the notecards were not graded. As one might expect, few students turned in notecards when they were not graded. A complete write-up of this trial-and-error period is available from the author by request.

${ }^{9}$ Indeed, a single student who joined the course late is responsible for two of the nineteen notecards not submitted. She did not miss any notecards after joining the course. Excluding these two notecards would increase the response rate to 97.15 percent $(512 / 527)$.
} 
the material from the podcast and had taken the time to reflect on it. The average score for the assignment was 0.95 (out of 1). If those earning a zero on the assignment are excluded, the average score increases to 0.99 .

\section{Survey}

After completing the course, students were emailed a link to a brief online survey. The survey was hosted by SurveyMonkey, which protects the identities of respondents while allowing the pollster to review (1) how all respondents replied to a single question and (2) how a single respondent replied to all questions. The survey requested responses to the following prompts:

1. I enjoyed listening to episodes of the Planet Money podcast.

2. The Planet Money podcast increased my interest in this course.

3. The Planet Money podcast helped me understand the relevance of macroeconomics.

4. Having listened to the Planet Money podcast, I have a better understanding of many macroeconomic issues.

5. Having listened to the Planet Money podcast, I feel more comfortable discussing many macroeconomic issues.

6. The Planet Money podcast allowed me to make use of time I might have otherwise wasted (e.g., listening while at the gym, getting ready, walking between classes, etc.).

7. Filling out notecards for the Planet Money podcast took too much time.

8. I liked knowing the course instructor would read and comment on my notecards.

9. I will continue listening to episodes of the Planet Money podcast after this course ends.

Each prompt limited answers to strongly agree, agree, neither agree nor disagree, disagree, and strongly disagree. Students were only permitted to select one answer for each question. ${ }^{10}$

Survey participation was very strong. Twenty-one of the course's twenty-three students participated, resulting in a 91.30 percent response rate. All respondents answered each of the nine prompts. Given the level of participation, one can be reasonably confident that

10 Students were also given the opportunity to answer the open-ended question, "What did you like most/least about the assignment?" Responses are available from the author upon request. 
the responses accurately reflect the opinions of all students in the course. Table 1 presents the survey results.

Table 1. Survey Results

\begin{tabular}{|c|c|c|c|c|c|}
\hline Survey Question & $\begin{array}{l}\text { Strongly } \\
\text { Agree } \\
(\%)\end{array}$ & $\begin{array}{l}\text { Agree } \\
(\%)\end{array}$ & $\begin{array}{l}\text { Neither } \\
\text { Agree Nor } \\
\text { Disagree } \\
(\%)\end{array}$ & $\begin{array}{l}\text { Disagree } \\
(\%)\end{array}$ & $\begin{array}{l}\text { Strongly } \\
\text { Disagree } \\
(\%)\end{array}$ \\
\hline $\begin{array}{l}\text { I enjoyed listening to } \\
\text { episodes of the Planet Money } \\
\text { podcast. }\end{array}$ & 28.57 & 61.90 & 9.52 & 0.00 & 0.00 \\
\hline $\begin{array}{l}\text { The Planet Money podcast } \\
\text { increased my interest in this } \\
\text { course. }\end{array}$ & 28.57 & 47.62 & 23.81 & 0.00 & 0.00 \\
\hline $\begin{array}{l}\text { The Planet Money podcast } \\
\text { helped me understand the } \\
\text { relevance of } \\
\text { macroeconomics. }\end{array}$ & 38.10 & 61.90 & 0.00 & 0.00 & 0.00 \\
\hline $\begin{array}{l}\text { Having listened to the Planet } \\
\text { Money podcast, I have a }\end{array}$ & & & & & \\
\hline $\begin{array}{l}\text { better understanding of } \\
\text { many macroeconomic } \\
\text { issues. }\end{array}$ & 19.05 & 66.67 & 14.29 & 0.00 & 0.00 \\
\hline $\begin{array}{l}\text { Having listened to the Planet } \\
\text { Money podcast I feel more }\end{array}$ & & & & & \\
\hline $\begin{array}{l}\text { comfortable discussing } \\
\text { many macroeconomic } \\
\text { issues. }\end{array}$ & 14.29 & 52.38 & 19.05 & 14.29 & 0.00 \\
\hline $\begin{array}{l}\text { The Planet Money podcast } \\
\text { allowed me to make use of } \\
\text { time I might have otherwise }\end{array}$ & & & & & \\
\hline $\begin{array}{l}\text { wasted (e.g., listening while } \\
\text { at the gym, getting ready, } \\
\text { walking between classes, } \\
\text { etc.). }\end{array}$ & 9.52 & 28.57 & 14.29 & 42.86 & 4.76 \\
\hline Filling out notecards for the & 000 & 1429 & 2381 & 57.14 & 4.76 \\
\hline $\begin{array}{l}\text { Planet Money podcast took } \\
\text { too much time. }\end{array}$ & 0.00 & 14.29 & 23.81 & $3 / .14$ & \\
\hline $\begin{array}{l}\text { I liked knowing the course } \\
\text { instructor would read and } \\
\text { comment on my notecards. }\end{array}$ & 14.29 & 57.14 & 19.05 & 9.52 & 0.00 \\
\hline $\begin{array}{l}\text { I will continue listening to } \\
\text { episodes of the Planet Money } \\
\text { podcast after this course } \\
\text { ends. }\end{array}$ & 4.76 & 42.86 & 23.81 & 23.81 & 4.76 \\
\hline
\end{tabular}

Overall, the survey results suggest that students receive the Planet Money podcast well and that the episodes seem to capture their attention. By students' own assessment, the podcast increases interest in the principles course, helps them understand the relevance of macroeconomics, and increases their understanding of many macroeconomic issues. Moreover, most indicate that they feel more 
comfortable discussing macroeconomic issues having listened to the podcast. Although students identified some problems, like the number of podcasts assigned and the extent of instructor feedback on students' notecards, it seems reasonable to conclude that NPR's Planet Money podcast is an effective addition to an introductory course in macroeconomics.

\section{Conclusion}

As Ben Stein illustrates in Ferris Bueller's Day Off, introductory courses in macroeconomics can be taught quite poorly. Many instructors focus almost exclusively on familiarizing students with aggregate constructs like gross domestic product and inflation. As a result, students often struggle to see the practical relevance. The alternative-plowing ahead like Mr. Stein-is not particularly attractive, either. If students never learn the basics, they will be unable to consider macroeconomics outside the highly structured environment of a classroom. What can be done?

I have offered a relatively simple solution that uses NPR's Planet Money podcast. Assigning episodes in advance of classroom meetings helps to increase students' awareness of macroeconomic concepts and to illustrate the material's practical relevance. Grading notecards where students summarize podcast episodes and provide questions or comments ensures that they actually listen to the episodes. And, provided that proper expectations are established early on, most of the benefits can be realized at little cost. Based on my experience and feedback received from students, I recommend that other instructors consider incorporating the Planet Money podcast in introductory macroeconomics courses.

\section{References}

Cowen, Tyler, and Alex Tabarrok. 2011. Modern Principles: Macroeconomics, 2nd ed. New York: Worth.

Diamond, Jr., Arthur M. 2009. "Using Video Clips to Teach Creative Destruction." Journal of Private Enterprise, 25(1): 151-61.

Ghent, Linda S., Misty Stone, and G. Dirk Mateer. 2011. "TV for Economics." Journal of Economic Education, 42(2): 207.

Hall, Joshua C. 2005. "Homer Economics: Using The Simpsons to Teach Economics." Journal of Private Enterprise, 20(2): 166-77.

Hall, Joshua C. 2012. "Incorporating EconTalk Podcasts into the Principles Classroom." Journal of Private Enterprise, 28(1): 113-18.

Hall, Joshua C., and Robert A. Lawson. 2008. "From ABBA to Zeppelin, Led: Using Music to Teach Introductory Economics." Perspectives in Economic Education Research, 4(1): 23-36. 
Hall, Joshua C., Robert A. Lawson, J. Dirk Mateer, and Andrew Rice. 2008. "Teaching Private Enterprise Through Tunes: An Abecedarium of Music for Economists." Journal of Private Enterprise, 23(2): 157-66.

Holian, Matthew J. 2011. "Using Drew Carey in the Classroom." Journal of Private Enterprise, 26(2): 161-67.

Lawson, Robert A. 2006. "Teaching Economic Principles with Comic Strips." Journal of Private Enterprise, 22(1): 168-76.

Mateer, G. Dirk. 2004. Economics in the Movies. Mason: Thomson/South-Western.

Mateer, G. Dirk, and E. Frank Stephenson. 2011. "Using Film Clips to Teach Public Choice Economics." Journal of Economics and Finance Education, 10(1): 2836.

Moryl, Rebecca. 2013. "T-shirts, Moonshine, and Autopsies: Using Podcasts to Engage Undergraduate Microeconomics Students." International Review of Economics Education, 13(1): 67-74.

National Public Radio. 2011a. "The Gold Standard." Planet Money, episode 252.

National Public Radio. 2011b. "The Gold Standard, R.I.P.” Planet Money, episode 253.

National Public Radio. 2011c. "Inside the Great Depression." Planet Money, episode 254.

National Public Radio. 2012a. "Keeping the Biggest Secret in the U.S. Economy." Planet Money, episode 392.

National Public Radio. 2012b. "Why the Price of Coke Didn't Change for 70 Years." Planet Money, episode 416. 